\title{
MEMANFAATKAN LIMBAH BATOK KELAPA MENJADI BERBAGAI MACAM BENTUK KERAJINAN
}

\author{
Rani Hermita \\ Universitas Potensi Utama Fakultas Seni dan Desain Program Studi Desain Interior \\ ranihermita@gmail.com
}

\begin{abstract}
ABSTRAK
Penelitian ini bertujuan bagaimana memanfaatan limbah batok kelapa menjadi berbagai macam bentuk kerajinan berbahan dasar batok kelapa. Bahan dasar yang berasal dari limbah batok kelapa yang dapat diperoleh dengan mudah di sekitar kita. Serta proses pengolahan limbah batok kelapa dengan menggunakan alat yang sederhana karena dapat dikerjakan dengan cara manual, sehingga dapat menjadi kerajinan dari limbah batok kelapa yang bernilai seni tinggi. Metode penelitian yang digunakan oleh penulis menggunakan metode penelitian kualitatif. Proses pengumpulan data yang dilakukan oleh penulis dengan beberapa cara yaitu pengamatan secara langsung proses pengolahan limbah batok kelapa, dokumentasi proses pengolahan limbah batok kelapa dan wawancara untuk mendapatkan data yang dibutuhkan. Berdasarkan hasil penelitian yang sudah dilakukan, penulis membagi menjadi dua jenis karya kerajinan batok kelapa yang dibuat oleh pengrajin yaitu; lampu hias dan asbak. Bahan dasar diperoleh dari pedagang kelapa yang sudah diambil daging buahnya dan para pengumpul batok kelapa, kemudian alat-alat yang diperlukan dalam pembuatan kerajian batok kelapa yaitu; batok kelapa kering, bor listrik kecil, kertas pasir, alat ukir, tang, lem kayu, pisau kecil, gunting besar, gergaji kayu, pengasah pisau, kuas cat, pensil, cutter kecil, air bersih, bola lampu, kabel dan cat pernis. Proses pengerjaan kerajinan dari batok kelapa dimulai dengan membersihkan batok kelapa dari sisa sabut kelapa dan kotoean yang menempel, kemudian batok kelapa direndam dengan air bersih selama 2 hari. Sebelum batok kelapa diukir menjadi bentuk motif yang diinginkan, terlebih dahulu membuat pola desain pada selembar kertas kemudian kertas tersebut ditempelkan pada permukaan batok kelapa, agar batok kelapa lebih mudah dipotong, diukir, dan dibentuk sesuai desain yang sudah dibuat pada permukaan batok kelapa tersebut. Selesai dilakukannya pengukiran diatas permuakaan batok kelapa kemudian karya dihaluskan dan diberi cat pernis kayu agar lebih kelihatan indah dan mengkilap.
\end{abstract}

Kata Kunci : Batok Kelapa, Kerajinan, Penelitian Kualitatif

\begin{abstract}
This study aims to use coconut shell waste into various forms of craft made from coconut shells. From the basic ingredients derived from coconut shell waste that can be easily obtained around us. As well as processing coconut shell waste using a simple tool because it can be done manually, so it can be a craft of coconut shell waste of high artistic value. The research method used by the author uses qualitative research methods. The process of data collection is carried out by the author in several ways, namely direct observation of coconut shell waste processing, documentation of coconut shell waste processing and interviews to obtain the data needed. Based on the results of the research that has been done, the author divides into two types of coconut shell craft works made by craftsmen namely; decorative lights and ashtrays. The basic ingredients are obtained from coconut traders who have already taken the fruit flesh and collectors of coconut shells, then the tools needed in making coconut shell processing are; dry coconut shell, small electric drill, sand paper, carving tools, pliers, wood glue, small knife, big scissors, wood saw, knife sharpener, paint brush, pencil, small cutter, clean water, light bulb, cable and varnish paint.
\end{abstract}


The process of crafting coconut shells starts with cleaning the coconut shell from the remaining coconut husk and kotoean sticking, then coconut shells soaked with clean water for 2 days. Before the coconut shell is carved into the desired motif, first make a design pattern on a piece of paper and paste it on the surface of the coconut shell, so that the coconut shell is easier to cut, carve and shape according to the design made on the coconut shell surface. After the engraving is done on the coconut shell surface then the work is smoothed and given a wood varnish to make it look more beautiful and shiny.

Keywords : Coconut Shell, Crafts, Qualitative Research

\section{PENDAHULUAN}

Tumbuhan kelapa di Indonesia merupakan tumbuhan serbaguna mulai dari akar, batang, bunga, buah sampai dengan daun dapat digunakan baik sebagai pengobatan tradisional ataupun untuk kehidupan sehari-hari seperti untuk bahan masakan dan kayu bakar, serta perabotan rumah tangga yang berbahan dasar pohon kelapa. Batang pohonnya dapat digunakan sebagai bahan bangunan perabotan rumah tangga, hiasan dan lain sebagainya. Daun kelapa dapat digunakan untuk pembungkus makanan terutama daun yang agak muda dan bila dianyam dapat digunakan untuk atap rumah sedangkan lidinya selain untuk membuat sapu juga untuk barang kerajinan tangan, seperti taplak meja, alas piring makan, tirai, tempat koran hiasan dinding ataupun aksesoris rumah tangga lainnya. Daun dan bunga yang masih muda dapat dijadikan bahan sayur. Sabut buah kelapa bila dianyam dapat menjadi keset, kasur, tali sabut kelapa, dan sebagian besar lainnya untuk bahan bakar secara langsung atau dalam bentuk arang. Pohon kelapa yang bermanfaat serbaguna ini, bila dilihat dari nilai jual yang kurang berharga adalah tempurung kelapa apalagi bila sudah berwujud limbah.

Limbah dari batok kelapa yang biasanya akan dibuang begitu saja oleh sebagian orang akibatnya banyak batok kelapa yang menjadi limbah yang mengganggu lingkungan. Bagi sebagian masyarakat, batok kelapa mungkin tidak berguna lagi karena merupakan sebuah limbah. Padahal sebenarnya batok kelapa justru mempunyai nilai dan sangat berguna untuk dijadikan kerajinan, sehingga banyak orang-orang kreatif yang mendaur ulang limbah batok kelapa menjadi suatu barang yang mempunyai nilai seni. Kerajinan dari bahan dasar limbah batok kelapa banyak dijadikan sebagai aksesoris dengan berbagai macam bentuk dan ukuran. Mulai dari hiasan rumah seperti lampu hias dan asbak.

Peminat dari produk kerajinan batok kelapa ini mungkin semakin meningkat seiring dengan perkembangan zaman. Bentuk produk dari hasil kerajinan batok kelapa yang memiliki serat yang unik dan klasik yang berasal dari batok kelapa itu sendiri serta bahan bakunya yang mudah di dapat yang berasal dari bahan alami yang berasal dari limbah kelapa, memiliki nilai lebih karena ramah lingkungan dan tahan lama, lebih mengutamakan kerajinan tangan dalam proses pembuatannya, dan memiliki estetika tinggi.

Pengolahan limbah dari batok kelapa sebagai hasil dari produk kerajinan tergolong ke dalam industri kerajinan yang paling membutuhkan kreatifitas dan pengembangannya untuk meningkatkan nilai estetikanya ${ }^{[4]}$. Untuk itu, batok kelapa yang digunakan untuk dijadikan kerajianan adalah batok kelapa yang berusia antara usia 11 bulan pemilihan batok kelapa berusia sedang karena lebih tahan lama. Berdasarkan hal tersebut, penelitian ini tidak mengikut sertakan batok kelapa berusia muda sebagai objek pembahasan ${ }^{[6]}$. Material batok kelapa berusia sedang dalam penelitian ini diperoleh dari sisa pemanfaatan buah kelapa dari industri rumah tangga. 


\section{STUDI LITERATUR}

II.1 Sebagai bahan refensi pertama meninjau penelitian karya Dewi Pugersari, Achmad Syarief \& Dwinita Larasati. Program Studi Magister Desain, Fakultas Seni Rupa dan Desain, Institut Teknologi Bandung tentang pemaparan yang telah dilakukan pada bagian latar belakang masalah, kemudian bagaimana mengolah tempurung kelapa yang berusia muda menjadi kerajian. Tujuan untuk menghasilkan karya seni dari limbah tempurung kelapa yang berusia muda dengan teknik pelunakan ${ }^{[5]}$.

II.2 Sebagai bahan referensi kedua meninjau penelitian Dina Arfadiani \& Dr. Dwinita Larasati. Program Studi Sarjana Dengan Produk, Fakultas Seni Rupa dan Desain Institut Teknologi Bandung pemaparan yang telah di jelaskan pada latar belakang tentang pemanfaatan limbah tempurung kelapa diolah menjadi peralatan makan seperti sendok. Tujuan dari penelitian ini adalah untuk mengurangi limbah dari tempurung kelapa yang dapat dijadikan sebagai alat rumah tangga ${ }^{[1]}$.

II.3 Sebagai bahan referensi ketiga meninjau penelitian Edy Eskak. Balai Besar Kerajinan dan Batik pemaparan yang telah dijelaskan pada latar belakang tentang identifikasi pola laminasi tempurung kelapa. Tujuan penelitian ini tempurung kerapa dapat diaplikasikan ke berbagai media perabotan rumah tangga ${ }^{[3]}$.

\section{PEMBAHASAN}

Pohon kelapa sangat mudah di temui di kepulauan Indonesia karena memiliki iklim tropis, kelapa memiliki batok kelapa dengan ketebalan dan keras. Kekerasan dari batok kelapa juga berpengaruh pada umur pakai peralatan yang dihasilkan. Pada penelitian ini bertujuan untuk memanfaatkan limbah batok kelapa yang bertujuan dalam upaya yang dilakukan dalam pemanfaatan batok kelapa sebagai material untuk dijadikan hiasan rumah yang memiliki nilai eknomis. Kualitas yang diharapkan dalam penggunaan bataok kelapa sebagai material sebagai hiasan rumah antara lain berupa visual dan tekstur, keawetan, dan usia ketahanan dari batok kelapa tersebut.

Batang pohon kelapa biasanya dijadikan papan atau tiang sebagai bahan bangunan yang tahan terhadap cuaca. Daun kelapa biasanya digunakan sebagai bahan dasar membuat ketupat. Kemudian tulang daunnya atau sering disebut lidi dapat digunakan sebagai sapu lidi. Pelepah daunnya dapat digunakan sebagai kayu bakar sebagai pengganti kompor. Daging buahnya yang masih muda biasanya dijadikan minuman atau yang sering disebut sebagai es kelapa muda, sedangkan daging kelapa yang sudah tua dapat digunakan sebagai bahan santan untuk makanan atau untuk membuat minyak goreng atau minyak urut.

Salah satu yang sangat menarik dalam memanfaatkan bagian-bagian dari kelapa terletak pada batok atau yang disebut dengan cangkang buahnya. Hal ini bahwa batok kelapa mempunyai nilai ekonomi yang jauh lebih tinggi dibandingkan dengan buah kelapanya itu sendiri apabila pandai dalam proses pengolahan dari batok kelapa. Dengan adanya kratifitas dan ketekunan dari tangan-tangan yang kreatif, batok kelapa dapat menjadi benda-benda kerajinan yang mempunyai kegunaan dan nilai seni. Sebelum diolah menjadi kerajinan batok kelapa di remdam kedalam air untuk menghilangkan sisa-sisa dari daging kelapanya agar lebih mudah dibersihkan. 


\section{Karakteristik Tempurung Kelapa}

Beberapa karakteristik yang dimiliki oleh batok kelapa adalah sebagai berikut:

1. Bersifat keras

Batok kelapa memiliki sifat yang keras karena memiliki serat pada strukturnya. Hal ini yang mengakibatkan batok kelapa dipotong secara manual atau menggunakan alat bantu sperti mesin pemotong.

2. Ketebalan batok kelapa yang tidak merata

Batok kelapa memiliki ketebalan yang tidak merata sehingga dalam proses pembentukan harus memiliki keahlian dan ketelitian karena sangat mempengaruhi dari bentuk yang dihasilkan.

3. Batok kelapa memiliki motif yang khas

Batok kelapa memiliki motif yang khas yang terbentuk dari garis urat serabut. Motif yang khas ini dapat memberikan nilai estetika tersendiri.

4. Kuat

Batok kelapa memiliki kekuatan yang baik tidak mudah pecah apabila terjatuh.

5. Tahan terhadap air

Batok kelapa tahan terhadap air karena miliki pori-pori yang sangat rapat. Sehingga batok kelapa dapat menahan air.

\section{Pemanfaatan Limbah Batok Kelapa}

Batok kelapa merupakan bagian dari buah kelapa yang masih belum banyak dimanfaatkan dibandingkan bagian buah kelapa lainnya seperti batang, daun dan lidinya, meskipun sebagian kecilnya masyarakat sudah mengolahnya menjadi arang. Selain dimanfaatkan sebagai bahan baku arang batok, batok kelapa secara karakteristik dapat digunakan sebagai bahan baku dari kerajinan limbah batok kelapa. Pemanfaatan limbah batok kelapa sebagai bahan baku kerajinan dapat dilakukan dengan beberapa teknik yang telah diterapkan oleh pengrajin batok kelapa. Berdasarkan hasil wawancara dengan Sumardi, Pengerajin batok kelapa yang beralamat Jl. Pancing, Indra Kasih, Medan Tembung, Kota Medan, Sumatera Utara, November 2018, teknik pembuatan kerajinan menggunakan bahan baku limbah batok kelapa dapat dibedakan menjadi tiga, yaitu teknik potong, teknik ikat atau rakit dan teknik laminasi.

Batok kelapa berasal dari bagian batok kelapa yang masih belum banyak dimamfaatkan dibandingkan bagian buah kelapa lainnya, walaupun sebagian kecil sudah diolah menjadi arang. Selain dimanfaatkan sebagai bahan baku dari arang secara karakteristik visualnya, batok kelapa juga dapat dimanfaatkan sebagai bahan utama pembuatan kerajianan. Pemanfaatan limbah batok kelapa sebagai bahan dasar kerajian dapat dilakukan dengan beberapa teknik oleh pengerajin batok kelapa.

a. Kelapa

Kelapa merupakan buah yang umumnya tumbuh didaerah tropis yang memiliki ciri khas daunnya seperti jarum dan umumnya tumbuh bergerombal di daerah pantai.

b. Batok Kelapa

Adalah kulit yang ada dibuah kelapa atau cangkang yang digunakan untuk melindungi buah kelapa yang ada di dalamnya. Tempurung kelapa adalah bahan yang melindungi buah kelapa yang memiliki struktur keras dan berserabut dibandingkan dengan bagian buah kelapa yang lain 


\section{c. Limbah}

Limbah merupakan sesuatu yang dihasilkan dari penggunaan suatu produk dimana limbah tersebut dapat diolah kembali dan dimanfaatkan menjadi barang yang memiliki nilai ekonomis di tangan yang kreatif dalam mengelolahnya.

\section{Tujuan Pemanfaatan Limbah Batok Kelapa}

Tujuan dari pemanfaatan batok kelapa adalah untuk mengurangi limbah batok kelapa yang berasal dari sisa penggunaan buah kelapanya. Batok kelapa dapat dijadikan benda yang berharga dan mempunyai nilai apabila dapat mengolahnya dengan baik. Limbah batok kelapa bukan hannya dapat langsung dibakar sebagai kayu bakar pengganti kompor, atau diolah menjadi arang batok kelapa. Tetapi batok kelapa juga bisa dimanfaatkan sebagai kerajinan. Namun tanpa dapat kita sadari, penggunaan dari limbah batok kelapa ini sangatlah menguntungkan. Kita dapat melihatnya dari segi ekonomisnya dan batok kelapa dapat di temukan dengan mudah dan terdapat dimana saja. Batok kelapa yang sudah tidak terpakai ini merupakan dapat digunakan untuk kerajianan hiasan rumah ${ }^{[8]}$.

\section{Metode Penelitian}

Beberapa metode yang digunakan dalam penulisan karya ilmiah ini diantaranya:

\section{A. Metode Penelitian Kualitatif}

Metode penelitian kualitatif merupakan penelitian yang biasanya digunakan untuk menyelidiki sebuah permasalahan, menemukan permasalahan, menggambarkan sebuah permasalahan, serta menjelaskan kualitas atau keistimewaan dari pengaruh sosial masyarakat yang tidak dapat dijelaskan secara langsung, diukur atau digambarkan tanpa melalui pendekatan kuantitatif. Sehingga penulis menggunakan metode kualitatif dalam penelitian ini agar hasil dari penelitian ini sesuai dengan yang diinginkan ${ }^{[7]}$.

Langkah-langkah dalam pelaksanaan penelitian kualitatif bersifat menyesuaikan sesuai dengan kebutuhan, serta situasi dan kondisi yang terjadi di lapangan. Secara garis besar ada beberapa tahapan dalam penelitian kualitatif adalah sebagai berikut ${ }^{[2]}$ :

1. Merumuskan masalah sebagai objek penelitian.

2. Mengumpulkan data yang ada di lapangan sebagai bahan acuan.

3. Menganalisis data yang sudah ada.

4. Merumuskan hasil studi yang sudah ada.

5. Menyusun saran untuk membuat sebuah keputusan penelitian. 


\section{B. Unsur Estetika}

1. Unsur Estetika

Produk kerajinan dari bahan keras seperti batok kelapa yang diubah menjadi lampu hias dan asbak. Permukaan batok kelapa dihaluskan agar terlihat lebih menarik. Penulis memperhatikan produk yang dihasilkan dari batok kelapa dari segi bentuk, warna yang tidak mencolok tetapi unsur kesatuan yang menjadi prioritas utama serta tekstur yang tidak terlalu kasar.

2. Keseimbangan

Penulis menerapkan unsur ini pada tekstur produk yang dibuat yaitu lampu hias dan asbak, produk yang sama besar sehingga terlihat seimbang dan memenuhi unsur keseimbangan.

3. Keselarasan

Lampu hias dari batok kelapa disesuaikan dengan tujuan utama yaitu sebagai benda yang memiliki nilai ekonomis yang berasal dari limbah batok kelapa.

4. Kontras

Penulis memberi corak dan motif produk agar lebih menarik dan indah.

\section{Pengamatan (Observasi) Secara Langsung}

Pengamatan terhadap kemampuan batok kelapa, dan bahan pendukung produk dilakukan untuk melihat kemampuan daur ulang atau kemampuan seluruh komponen pembentuk produk untuk diuraikan oleh alam. Berikut beberapa pengamatan terhadap komponen pembuatan kerajinan dari limbah batok kelapa.

\section{Batok Kelapa}

Batok kelapa merupakan material yang dapat diuraikan secara alami oleh mikroorganisme di dalam tanah. Batok kelapa, baik batok kelapa tanpa proses lanjutan maupun batok kelapa sisa hasil proses produksi, batok kelapa dapat membusuk dan terurai dengan sendirinya oleh alam. Sisa batok kelapa hasil produksi yang tidak terpakai dapat dijadikan pupuk dalam keadaan basah, sedangkan batok kelapa hasil sisa produksi kering dapat dibuang begitu saja dialam karena kemampuannya untuk terurai dengan sendirinya tanpa melalui proses yang dibuat untuk menguirainya.

\section{Pemilihan Batok Kelapa}

Pada tahap pemilihan batok kelapa juga tidak sembarangan. Batok kelapa yang digunakan juga yang sudah berusia agak tua karena dari segi ketahan batok kelapa yang berusia tua juga memiliki corak yang lebih bagus dan menarik karena warna batok kelapa yang sudah agak tua berwarna coklat kehitaman. Apabila dijadikan sebuah kerajianan akan memberikan corak yang khas yang berasal dari serat batok kelapa itu sendiri.

\section{Proses Poduksi}

Proses produksi merupakan proses dari pengolahan bahan dasar menjadi bahan jadi. Proses produksi untuk menghasilkan suatu produk barang atau jasa. Proses produksi disebut juga sebagai kegiatan mengolah bahan baku dan bahan pembantu dengan 
memanfaatkan peralatan sehingga menghasilkan suatu produk yang lebih bernilai dari bahan dasarnya.

\section{Finishing}

Penyempurnaan produk (finishing) dilakukan untuk membuat permukaan batok kelapa tidak terlihat kusam dan lebih mengkilat. Proses terdiri dari penghalusan permukaan produk dan penggosokan untuk mendapatkan permukaan yang lebih mengkilat. Terdapat dua pilihan bahan pendukung yang dapat digunakan untuk mengkilatkan permukaan produk yaitu daun pisang kering, kertas pasir dan alat untuk menghaluskan atau yang disebut mesin ketam.

\section{Perancangan dan Realisasi}

Lampu hias dan asbak dari limbah batok kelapa dapat dijadikan sebagai hiasan yang indah dan menarik untuk menjadi pajangan dirumah ataupun di kantor. Dengan bahan limbah batok kelapa yang sangat mudah kita temui di sekitar lingkungan tempat tinggal dan dijadikan hiasan rumah yang menarik.

\section{Tahapan Pembuatan Kerajinan Berbahan Dasar Limbah Batok Kelapa}

\begin{tabular}{|c|c|c|c|}
\hline Bahan Dasar & Proses Pengolahan & Penghalusan & Finishing \\
\hline 1. Batok Kelapa & 1. Membuat Motif & 1. Menghaluskan & 1. Tahap Akhir Dari \\
\hline 2. Membersihkan & Pada Permukaan & Permukaan Batok & Proses Produksi \\
\hline Batok Kelapa & Batok Kelapa & Kelapa Dengan & \\
\hline Dari Serabut & 2. Proses Pengukiran & Kertas Pasir & \\
\hline
\end{tabular}

\section{Bahan dan Alat Yang Di Gunakan}

- Limbah Batok Kelapa Kering

- Kertas Pasir

- Bor Listrik Yang Berukuran Kecil

- Alat Ukir

- Lem Kayu

- Cat Pernis

- Bola Lampu

- Kikir

- Pisau

- Gunting Besar

- Gergaji Kayu

- Batu Asah Pisau

- Kuas Untuk Mengecat

- Pensil Untuk Menggambar

- Cutter Kecil

- Air Bersih

- Tang Kecil

- Kabel Listrik 
Proses Pengerjaan Lampu Hias Dengan Bahan Limbah Batok Kelapa

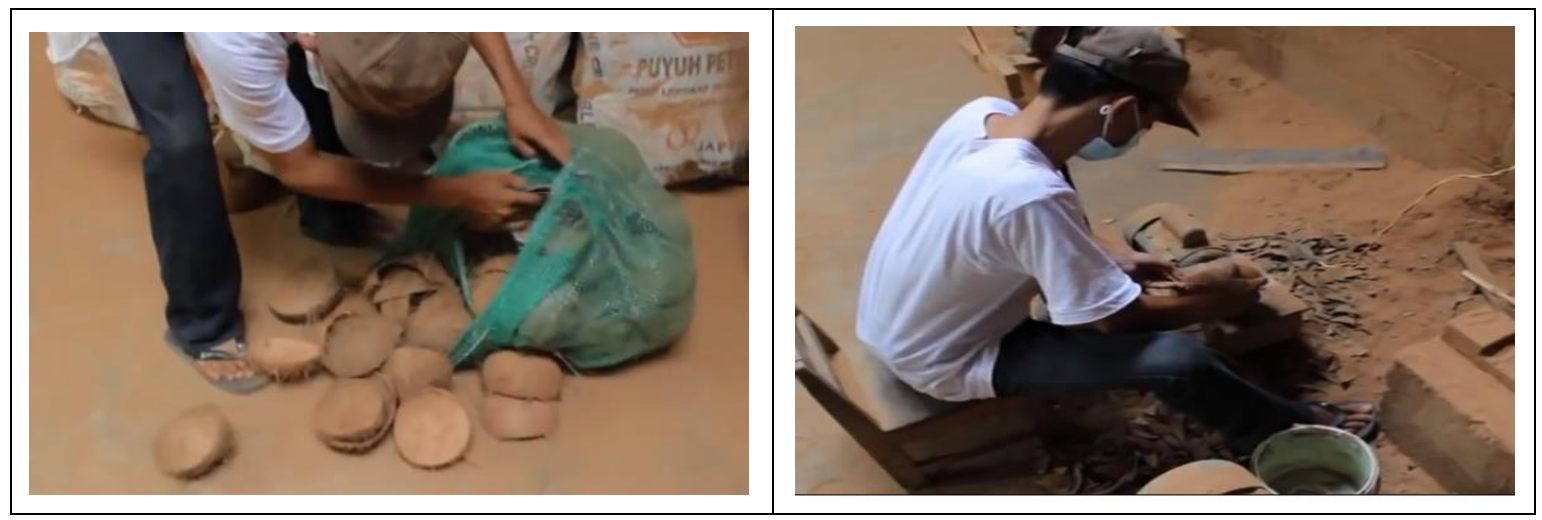

Gambar 1. Proses Pemilihan Batok Kelapa dan Pemotongan Batok Kelapa

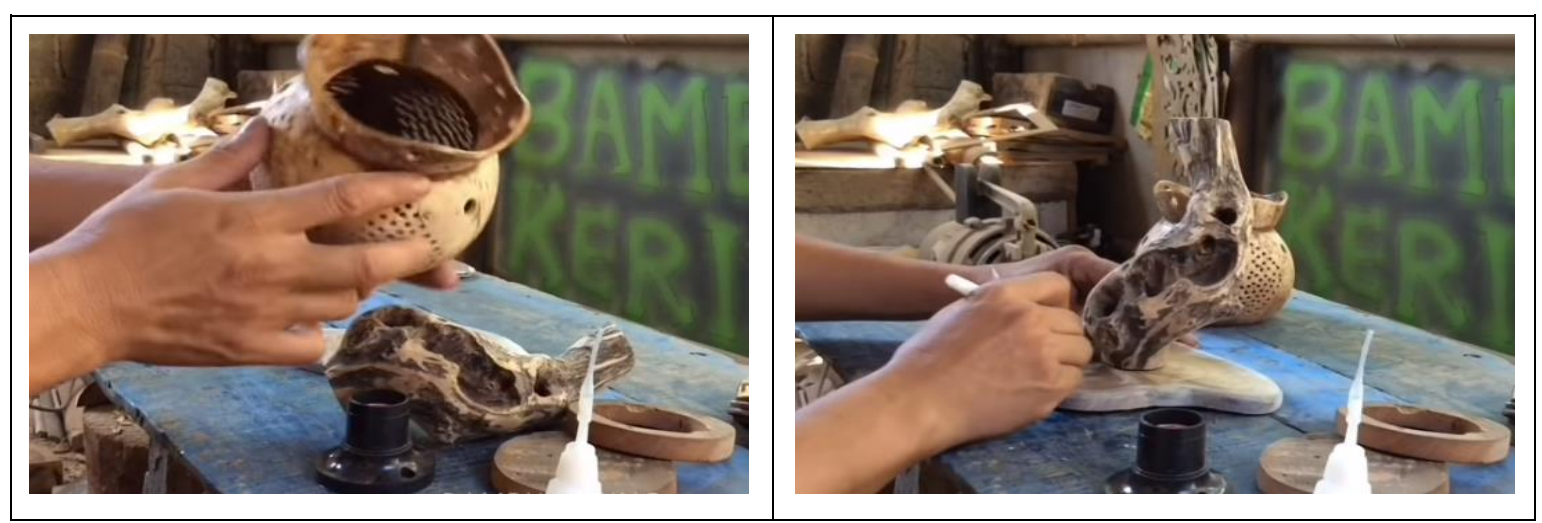

Gambar 2. Proses Penyatuan Batok Kelapa Dengan Penyanggah

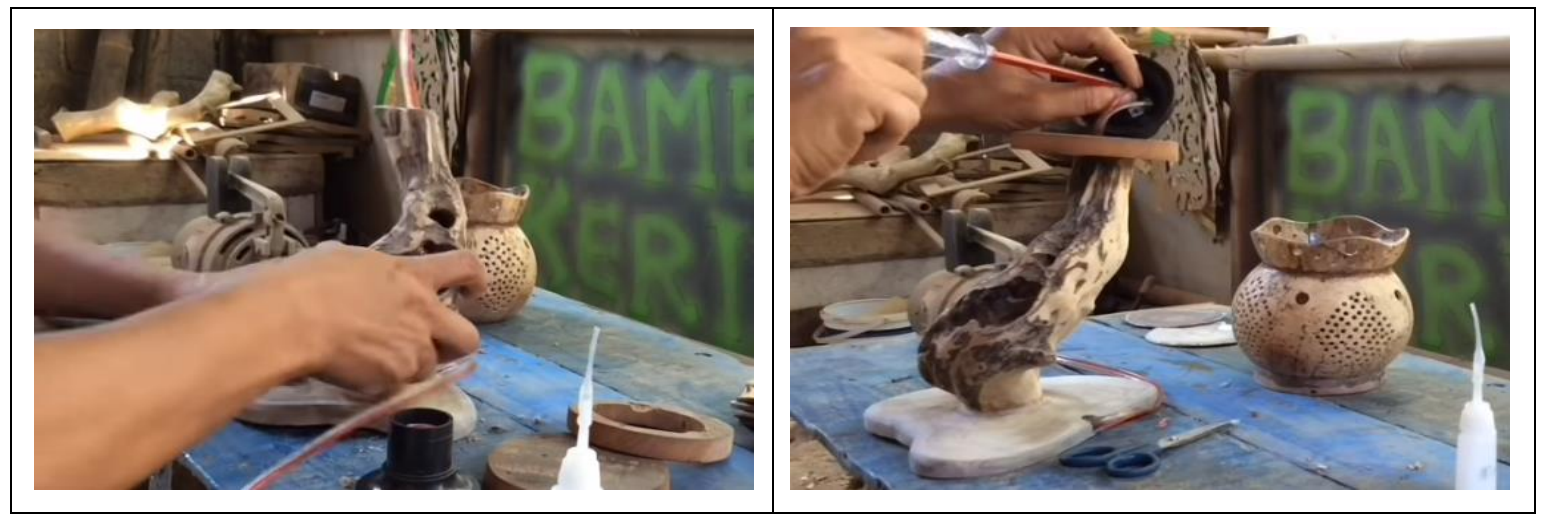

Gambar 3. Proses Pemasangan Bola Lampu 


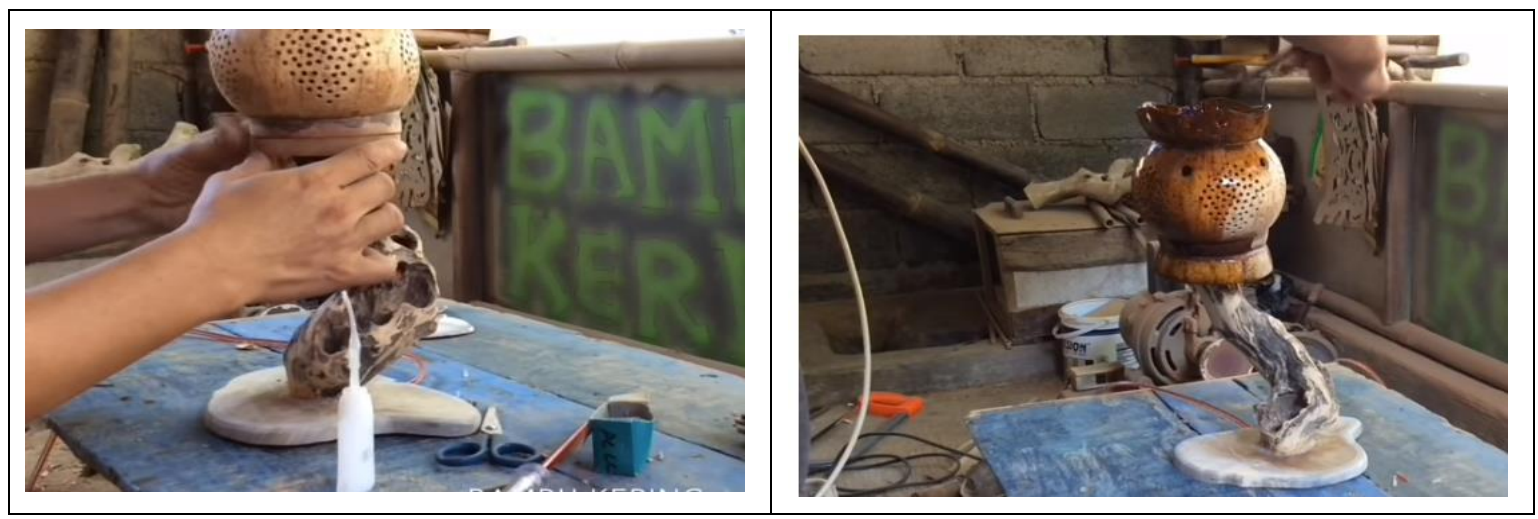

Gambar 4. Proses Pemasangan Kaki Lampu

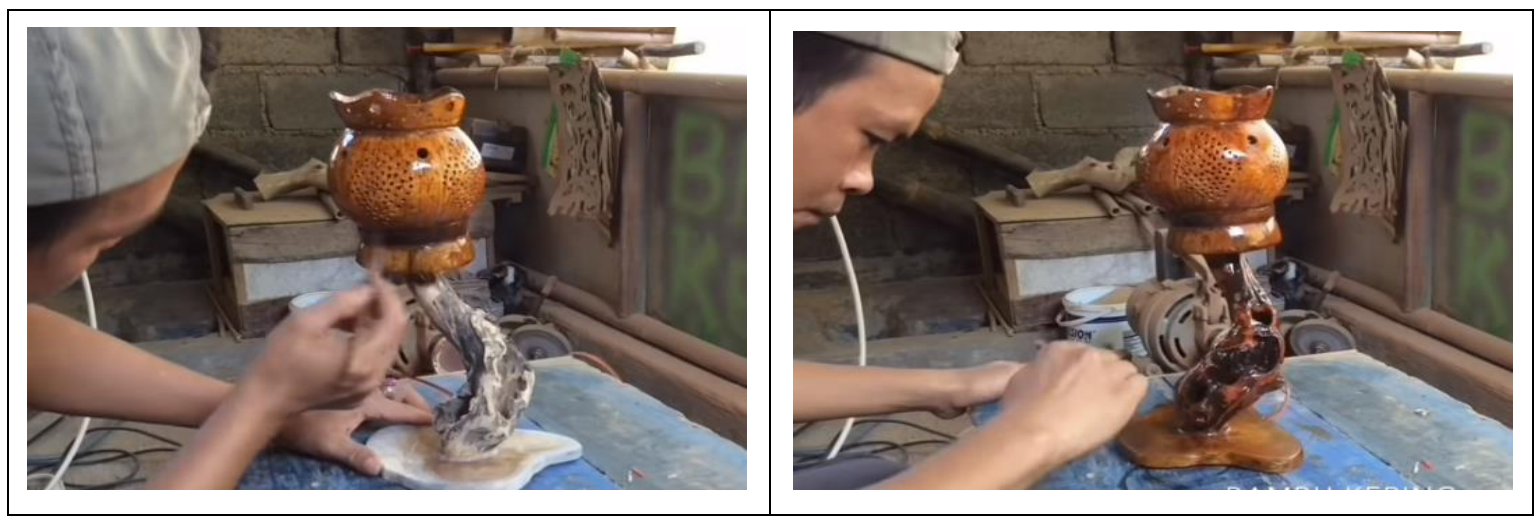

Gambar 5. Proses Pengecatan Batok Kelapa

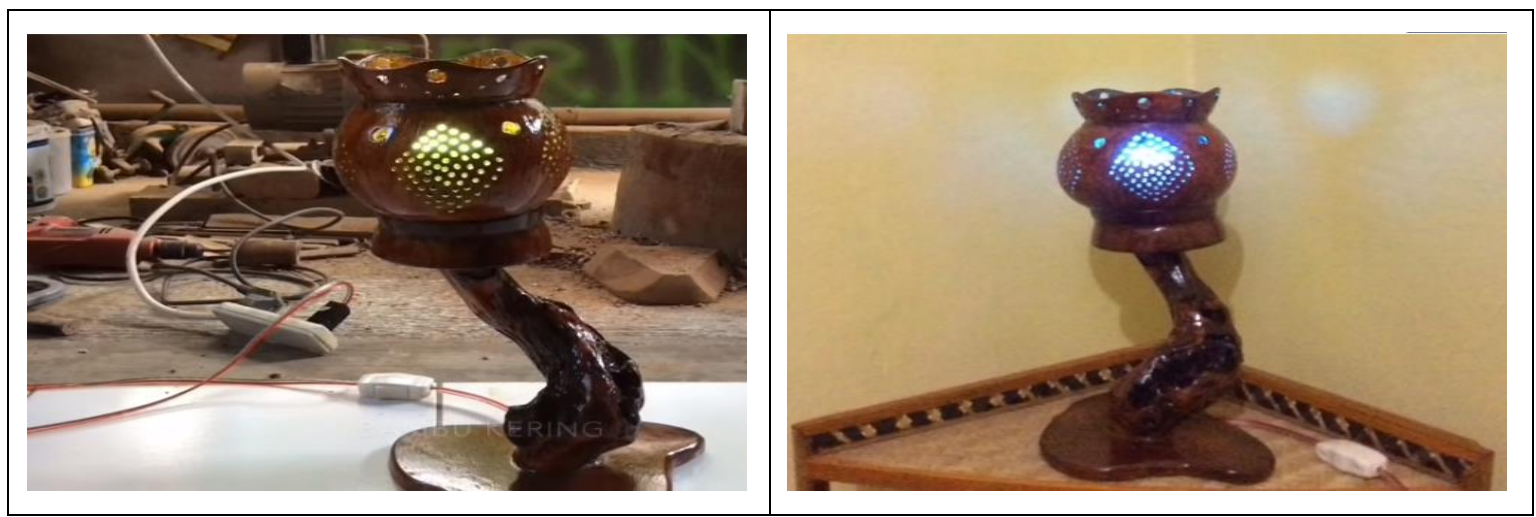

Gambar 6. Hasil Dari Lampu Berbahan Batok Kelapa

\section{Proses pembuatan}

1. Batok kelapa dibersihkan dari sisa sabut kalapa pada bagian permukaannya

2. Permukaan batok kelapa yang sudah dihaluskan dengan kertas pasir dapat dibentuk sesuai dengan pola yang sudah dibuat sebelumnya

3. Buat lubang pada bagian tengah batok kelapa untuk menempatkan lampu

4. Bersihkan bagian dalam batok kelapa sampai bersih dari sisa kelapa

5. Bentuk permukaan batok kelapa yang sudah dibuat pola tadi seperti bentuk ornamen belah ketupat menggunakan alat ukir 
6. Buatlah kaki untuk lampu hias batok kelapa, kaki lampu bisa dibuat dari batok juga atau dari kayu.

7. Rekatkan antara tempat lampu dan kaki lampu menggunakan baut

8. Beri warna pada batok kelapa menggunakan cat pernis agar warna lebih mengkilap.

9. Kabel bisa dililitkan pada kaki lampu membentuk pola yang menarik.

\section{Proses Pembuatan Asbak Dengan Bahan Batok Kelapa}

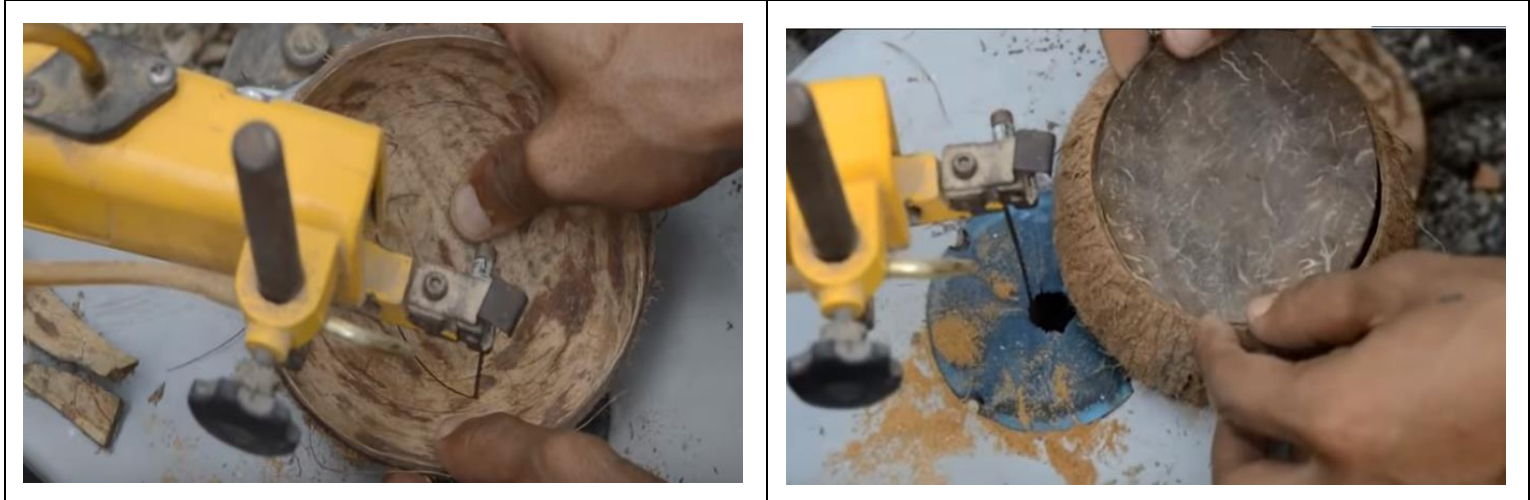

Gambar 7. Proses Pemotongan Batok Kelapa

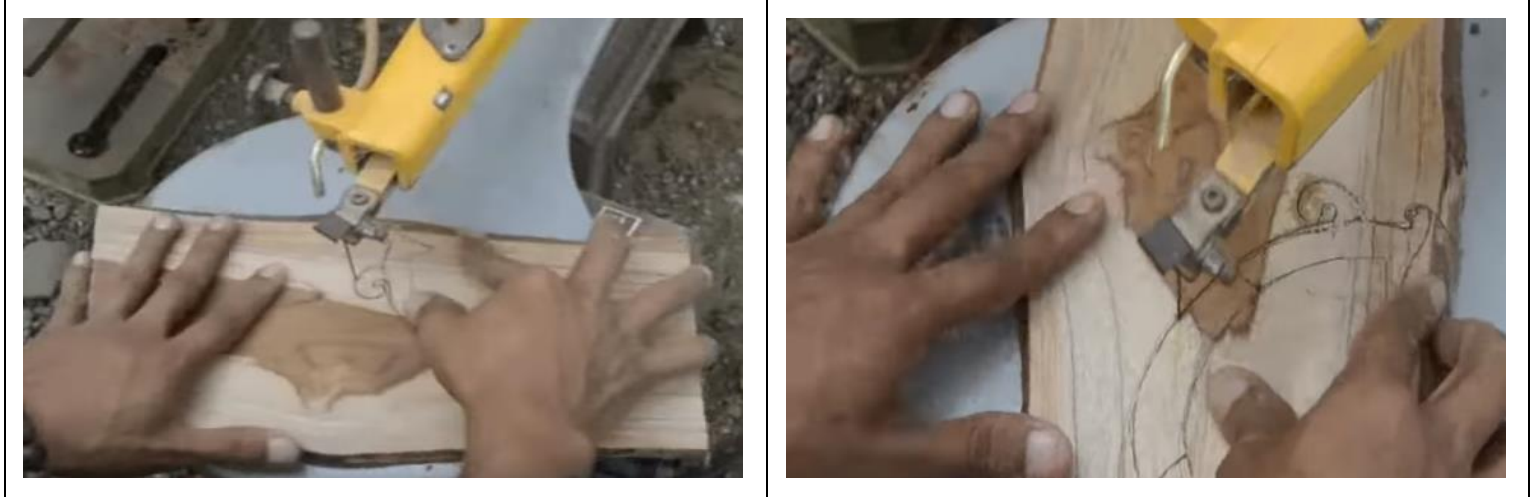

Gambar 8. Proses Pemotongan Kaki Asbak
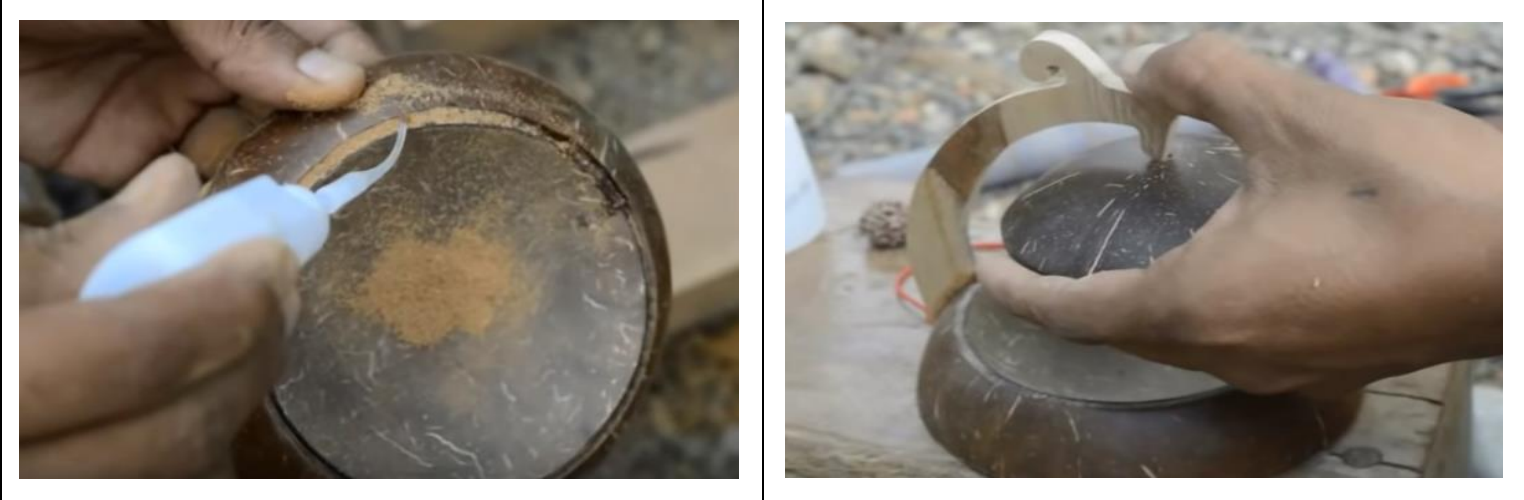

Gambar 9. Merangkai Asbak Berbahan Batok Kelapa 

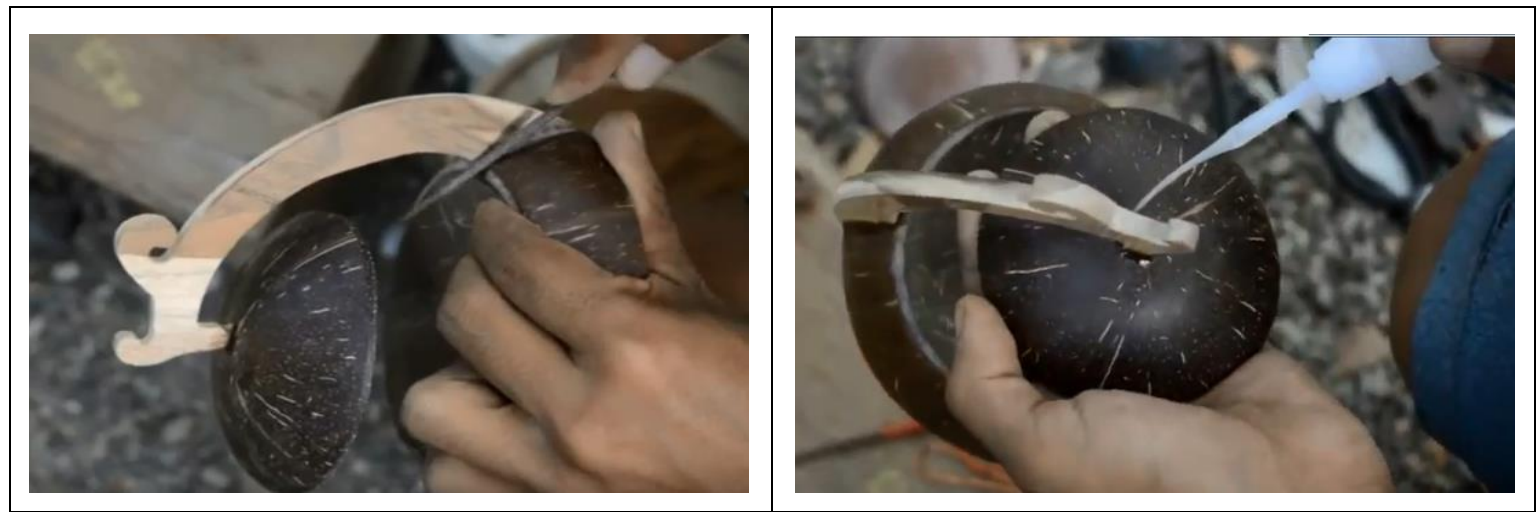

Gambar 10. Proses Penghalusan dan Pemasangan Kaki Asbak
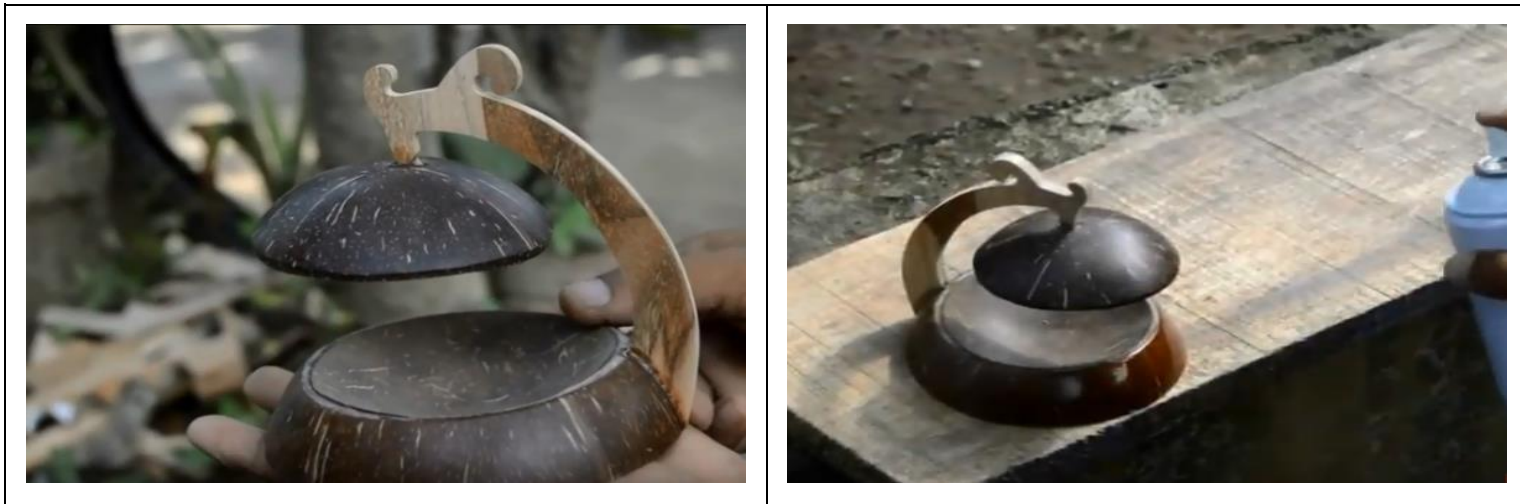

Gambar 11. Proses Pengecatan Asbak
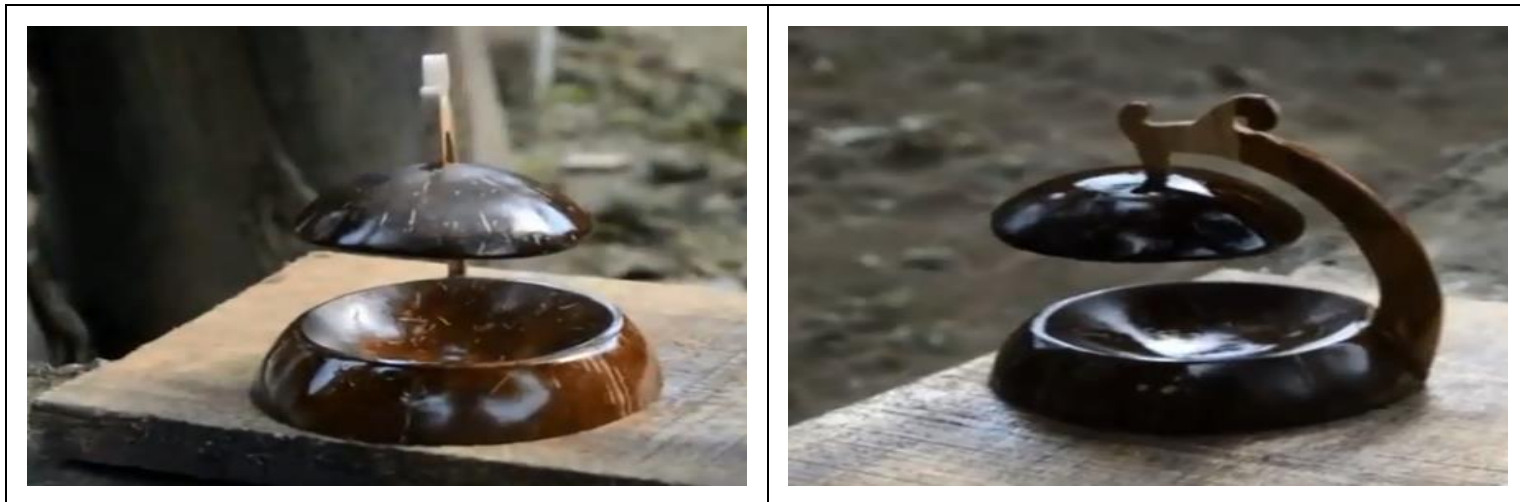

Gambar 12. Hasil Dari Asbak Berbahan Dasar Batok

\section{Proses pembuatan}

1. Bersihkan batok batok kelapa dari sisa sabut kelapa dan kotoran yang menempel. Kemudian haluskan permukaan batok kelapa menggunakan kertas pasir.

2. Belah batok kelapa menjadi 2 bagian yang tidak sama besar menggunakan gergaji. Belah dengan hati- hati. 
3. Lubangi bagian samping kelapa dengan bor. Kemudian sambungkan dengan kaki penyanggah asbak.

4. Setelah selesai penyatuan antara tempat asbak dengan kaki asbak maka asbak tersebut bentuknya akan terlihat menyerupai mangkuk. Sebelum asbak akan di cat, haluskan kembali permukaan asbak menggunakan kertas pasir agar kelihatan lebih halus.

5. Kemudian asbak bisa di cat dengan menggunakana cat pernis agar lebih mengkilap.

\section{KESIMPULAN}

Penelitian ini dilakukan untuk memanfaatkan limbah batok kelapa sebagai bahan dasar produk sehingga dapat meningkatkan nilainya. Limbah batok kelapa masih belum memiliki peluang pemanfaatan yang baik sehingga limbah dari batok kelapa mengalami peningkatan. Batok kelapa memiliki karakteristik yang berpotensi untuk dijadikan bahan dasar produk diantaranya memiliki ketahanan, keawetan serta sifatnya yang mampu menahan air. Batok kelapa berpeluang untuk dikembangkan sebagai bahan dasar dari produk untuk hiasan rumah. Seiring dengan maraknya produk dari bahan alam maka batok kelapa dapat dijadikan suatu alternatif yang potensial untuk kerajinan.

Keunikan dan nilai dari produk yang dihasilkan dari limbah batok kelapa yang dinilai memiliki potensi yang paling besar untuk terus dikembangkan menjadi berbagai produk kerajinan lainnya. Selain berbahan alami batok kelapa juga ramah lingkungan karena memiliki sifat yang dapat mengurai dengan tanah. Sehingga tidak perlu usaha keras untuk menagani sisa dari produksi batok kelapa.

\section{DAFTAR PUSTAKA}

[1] Arfadiani, Dina. (2013). Pemanfaatan Limbah Tempurung Kelapa Muda Melaui Pengembangan Desain Produk Alat Makan. Jurnal Seni Rupa dan Desain. ITB:Bandung.

[2] Danim, Sudarwan \& Darwis (2003). Prosedur Kebijakan dan Etik. Jakarta: Penerbit Kedokteran EGC.

[3] Eskak, Edi. (2015). Identifikasi Pola Laminasi Tempurung Kelapa. Dinamika Kerajinan dan Batik. Balai Besar Kerajinan dan Batik Vol. 32:Yogyakarta.

[4] Pangestu, M.E. (2008). Pengembangan Industri Kreatif Menuju Visi Ekonomi Kreatif Indonesia 2025, Jakarta: Departemen Perdagangan RI.

[5] Pugersari, Dewi. (2011). Eksperimen Pengembangan Produk Fungsional Bernilai Komersial Berbahan Baku Tempurung Kelapa Berusia Muda Dengan Teknik Pelunakan. Jurnal Vis Art Vol.5. ITB:Bandung.

[6] Rusvirman, M., Hernandi, S., Daslin, N. \& Silviea, N.A. (2010). Penelitian Pendahuluan Pemanfaatan Limbah Pedagang Air Kelapa Muda Bandung (makalah Jurusan Kimia Fakultas Matematikaa dan Ilmu Pengetahuan Alam), Cimahi: Universitas Jenderal Achmad Yani.

[7] Saryono, 2010. Metode Penelitian Kualitatif. Bandung: PT. Alfabeta.

[8] http://oyongtermaji.blogspot.com/ Diakses Tanggal 27 November 2018. 